\title{
Kórokozóspektrum egy hematológiai osztályon
}

\author{
Sipos Dávid ${ }^{1,}$, Nyul Adrienn², Kovács Krisztina², \\ Hussain Alizadeh ${ }^{3}$, Péterfi Zoltán ${ }^{1}$

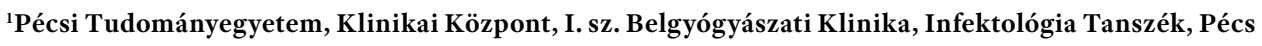 \\ ${ }^{2}$ Pécsi Tudományegyetem, Orvosi Mikrobiológiai és Immunitástani Intézet, \\ Bakteriológiai és Kórházhigiénés Laboratórium, Pécs \\ ${ }^{3}$ Pécsi Tudományegyetem, Klinikai Központ, I. sz. Belgyógyászati Klinika, Hematológiai Tanszék, Pécs
}

\begin{abstract}
Bevezetés: Míg korábban az antibiotikumok felfedezésével, klinikai alkalmazásával az orvostudomány jelentős előrelépést tett az infekciós kórképek kezelésében, a 21. században az antibiotikumok igen széles körü, gyakorta nem megfelelő felhasználásával e betegségek ismét reneszánszukat élik, a multirezisztens kórokozók pedig egyre nagyobb kihívást jelentenek a mindennapi orvoslásban. Különösen igaz ez a csökkent védekezőképességü betegekre. Mindezek szükségessé teszik, hogy az antibiotikumokat megfontoltan, az országos és helyi rezisztenciaviszonyoknak megfelelően alkalmazzuk. Célkitüzés: Egy hároméves periódusban felmérni tanszékünkön a véráramfertőzések leggyakoribb bakteriális kórokozóit, azok antibiotikum-érzékenységét és a multirezisztens kórokozók arányát. Módszer: A vizsgált időszakban a valós véráramfertőzést mutató pozitív hemokultúrás minták eredményeinek feldolgozása. Eredmények: A vizsgálati eredmények alapján tanszékünkön a véráramfertőzések legnagyobb részéért Gram-negatív kórokozók tehetőek felelőssé, előtérben az Enterobacteriaceae család tagjaival. Hematológiai betegek esetében megszokott módon, emellett fontos kórokozó a Pseudomonas aeruginosa. A Gram-pozitív baktériumok és multirezisztens kórokozók okozta véráramfertőzések gyakorisága kisebb. A Pseudomonas törzsek között magasabb carbapenemrezisztencia mellett kedvezőbb érzékenységi eredmények észlelhetőek piperacillin/tazobaktám, valamint cefepim tekintetében. Következtetések: Ahogy vizsgálatunk is mutatja, Hematológiai Tanszékünkön a Pseudomonas-ellenes antibiotikumok kiegyensúlyozott alkalmazásával sikerült egy olyan középutat megtalálni, amely mind a magas rizikójú betegcsoport empirikus kezelésének, mind pedig a multirezisztens kórokozók adta kihívásoknak meg tud felelni.
\end{abstract}

Kulcsszavak: hemokultúra, multirezisztens, antibiotikum-rezisztencia

\section{Spectrum of bacteria on a haematological ward}

Introduction: In the past, with the discovery and subsequent usage of antibiotics, medicine has made significant progress in the treatment of infectious diseases. However, in the 21st century, with the widespread and often inappropriate use of antibiotics, these diseases are re-emerging, and multidrug-resistant pathogens are increasingly challenging in everyday medicine. This is especially true for immunocompromised patients. Therefore, antibiotics should be used cautiously, based on national and local resistance data. Aims: Our goal was to assess the spectrum of most important bacterial pathogens causing bloodstream infections. Also, to evaluate their antibiotic susceptibility and the rate of multidrug-resistant bacteria in our haematology ward. Method: We examined results of the positive blood cultures during a threeyear period. Results: Based on data from our survey, the most common pathogenic bacteria causing bloodstream infections in our ward were Gram-negatives, the majority belonging to the Enterobacteriaceae family. In addition to these strains, Pseudomonas aeruginosa remains a common pathogen in haematology patients, too. Gram-positive and multidrug-resistant bacteria are less prevalent. Antibiotic susceptibility tests showed a higher resistance against carbapenem antibiotics among Pseudomonas aeruginosa isolates compared to cefepime or piperacillin/tazobactam. Conclusions: For an empiric antibiotic therapy in our haematology ward, compounds that have a good Gram-negative spectrum also covering Pseudomonas aeruginosa seem to be appropriate. With an antibiotic stewardship that aims at the balanced use of antipseudomonal beta-lactams we could achieve a sufficiently effective empiric antibiotic therapy that does not significantly increase the risk of multidrug-resistant infections.

Keywords: blood culture, multidrug-resistant bacteria, microbial drug resistance

(Beérkezett: 2019. február 6.; elfogadva: 2019. március 4.)

\footnotetext{
@ Levelezési cím: Dr. Sipos Dávid, PTE KK I. sz. Belgyógyászati Klinika, 7632 Pécs, Rákóczi út 2., Tel.: 06-30-469-7379, E-mail: sipos.david@pte.hu
} 


\section{Rövidítések}

$\mathrm{Qnr}=$ Quinolone-resistance (kinolon-rezisztencia); PBP = Penicillin Binding Protein (penicillinkötő fehérje); MALDI-TOF MS = Matrix-assisted laser desorption/ionization time-of-flight mass spectrometry (tömegspektrometrián alapuló mikrobiológiai diagnosztika); EUCAST = European Committee on Antibiotic Susceptibility Testing; MECO = Multirezisztens Escherichia coli; MKLE = Multirezisztens Klebsiella spp.; ESBL = Extended Spectrum Beta-Lactamase; MPAE = Multirezisztens Pseudomonas aeruginosa; VRE = Vancomycinrezisztens Enterococcus spp.; MRSA = Methicillinrezisztens Staphylococcus aureus

Az orvostudomány fejlődésével egyre több diagnosztikus és terápiás kihíváson tudunk felülkerekedni. A kórokozókkal szembeni küzdelem 1940-ben a penicillin klinikai alkalmazásával vette kezdetét, mely nagy áttörést jelentett az infekciók kezelésében. Ez a felfedezés azonban olyan versengést indított el a tudomány és a természet között, amelyben az eddig elért eredményekkel aligha tudtunk valósan úrrá lenni a kórokozókon. Az antibiotikumok igen elterjedt, sok esetben indokolatlan használata, nem megfelelő dózisban, ideig vagy indikációval történő alkalmazása a kórokozókat arra sarkallja, hogy vegyék fel a harcot a rendelkezésre álló gyógyszerekkel. Erre számos rezisztenciamechanizmus áll rendelkezésükre, úgymint az antibiotikumokat inaktiváló enzimek termelése (pl. bétalaktamázok, aminoglikozidmodifikáló enzimek), a kötőhelyek megváltozása (pl. Qnr génmediálta fluorokinolonrezisztencia, PBP megváltozása), különböző efflux pumpák vagy a permeabilitás csökkenése [1]. Ezekkel a mechanizmusokkal olyan multirezisztens kórokozók alakulnak ki és terjednek el egyre inkább, melyekkel szemben nem, vagy csak nagyon korlátozott számban rendelkezünk hatékony antibiotikumokkal. Mindezek a tényezők a multirezisztens kórokozókat a 21. század orvostudományának egyik legnagyobb kihívásává tették [2, 3].

Másrészről nem csupán a kórokozók megváltozott természete jelent nehézséget a napi gyakorlatban. A terápiás lehetőségek bővülésének köszönhetően egyre több betegséget tudunk kezelni, adott esetben akár gyógyítani is, ami az életkilátások javulásához, a várható élettartam növekedéséhez vezet. Ez ugyanakkor az alapbetegség természetéből adódóan vagy a kezelés mellékhatásaként olyan helyzetet teremt, amelyben a beteg esendőbb bizonyos fertőző ágensekkel szemben. Ilyen állapot például a diabetes, amelyet a neutrophil kemotaxis, a vascularis endothelhez való adhézió, a phagocytafunkció, valamint komplement mediálta phagocytosis hyperglykaemia okozta károsodása jellemez [4]. A felsorolt tényezők károsítják az extracelluláris kórokozókkal (pl. gennykeltő baktériumok, gombák) szembeni védekezést, így bakteriális, valamint gombasepsis kialakulását eredményezhetik. A krónikus veseelégtelenség, illetve egyes malignus betegségek okozta fehérjevesztés az antitestszint csökkenéséhez, a következményes katabolizmus pedig a T-sejtek müködésének zavarához vezet, mely a bakteriális fertőzések mellett a vírusinfekciók tekintetében is magasabb rizikót jelent. Hasonló következményekkel járhat különböző monoclonalis ellenanyagok és proteinkinázgátlók alkalmazása. Emellett a kemoterápia okozta neutropenia szintén az extracellularis kórokozók elleni védelem csökkenéséhez vezet.

Különösen nagy rizikójú betegcsoport a hematológiai betegségekben szenvedők köre, hiszen náluk mind az alapbetegség természetéből, mind pedig a kezelésből adódó immunszuppresszív hatásra számítanunk kell. Emellett különösen nehézzé teszi a megfelelő antibiotikum-választást az a körülmény, hogy ezek a betegek a gyakori infekciók miatt több alkalommal részesülnek antibiotikum-kezelésben, gyakrabban szorulnak hospitalizációra. Mindennek folytán ebben a betegpopulációban az infekciók rapid lefolyása miatt igen nagy szerepe van a korai, megfelelő empirikus antibiotikus terápiának, amely nélkül a mortalitás jelentősen megemelkedik. Ezt támasztja alá Weinstein és mtsai által, kanülinfekcióban szenvedő betegek körében végzett vizsgálat is. Jól megválasztott empirikus antibiotikum-kezeléssel a mortalitás $10 \%$ körüli volt. Amennyiben a kezdetben inadekvát empirikus kezelést az izolált kórokozó ismeretében megfelelően módosították, úgy a halálozás 13\%-nak adódott, amennyiben viszont a helytelen empirikus kezelést csak az antibiogram ismeretében cserélték célzott terápiára, úgy a mortalitás $26 \%$-ra emelkedett [5].

Ilyen helyzetekben segítenek a döntésben a különböző ajánlások, irányelvek. Nem szabad ugyanakkor elfelejteni, hogy a sikeres empirikus antibiotikum-kezelés elengedhetetlen feltétele a rezisztenciaviszonyok, különösen a lokális eredmények ismerete. A multirezisztens kórokozók térhódításával viszont egyre nehezebb lesz a megfelelő empirikus antibiotikum-választás. A döntésben segíthetnek az országos surveillance eredményei is. A multirezisztens kórokozók arányának, antibiotikum-érzékenységének ismerete különösen fontos olyan osztályokon (mint pl. hematológia, intenzív osztály), ahol az ápolt betegek vonatkozásában jelentős az antibiotikumok okozta szelekciós nyomás. Erre hívja fel a figyelmet az Országos Epidemiológiai Központ vonatkozó irányelve is [3]. A felsorolt információk figyelembevételével tudunk olyan, a fenti kritériumoknak megfelelő antibiotikumstewardship elveket követni, amelyek nemcsak a beteg gyógyulását eredményezik, de a multirezisztens mikrobák okozta veszélyeket is csökkentik.

A hematológiai osztályon kezelt betegek (különösen 7 napon túl tartó, <0,1 G/1 abszolút neutrophil számmal jellemzett neutropenia esetén) a fentiek folytán igen nagy veszélynek vannak kitéve a különböző fertőző ágensekkel szemben. Az 1960-70-es években - a citotoxikus kemoterápia bevezetésével - a Gram-negatív törzsek kóroki szerepe emelkedett meg, amelyet a 80-as években az intravascularis müanyag eszközök térhódításával a Gram-pozitív baktériumok dominanciája váltott fel. Jelenleg a hemokultúrákból leggyakrabban izolált koaguláz-negatív Staphylococcusok mellett az Enterobcteriaceae család tagjai (E. coli, Klebsiella spp., Enterobacter spp.), továbbá a 
nem fermentáló Gram-negatívok, (mint a $P$. aeruginosa, az Acinetobacter spp., a $S$. maltophilia), illetve ezek multirezisztens törzsei jelentik a legnagyobb kihívást [6, 7]. Egy Gedik és mtsai által 2014-ben az isztambuli Okmeydani oktatókórházban elvégzett vizsgálat bacteraemiák tekintetében 74\%-os Gram-negatív dominanciát talált. $\mathrm{Az}$ izolátumok jelentős része ebben a vizsgálatban is az Enterobacteriaceae család tagja volt, amelynek hátterében a kemoterápia okozta barrierkárosodás talaján kialakult endogén fertőzés oki szerepe valószínűsíthető. Az igazolt bacteraemiák 14\%-át multirezisztens Gram-negatívok, 7\%-át multirezisztens Gram-pozitívok okozták [6].

A kórokozóspektrum alapján neutropeniás betegek esetén empirikus kezelésként monoterápiában egy antipseudomonas aktivitással bíró cefalosporin (pl. cefepim), carbapenem- vagy piperacillin/tazobaktámkezelés javasolható. Empirikus vancomycinkiegészítés csak válogatott betegpopulációt tekintve (pl. kanülinfekció, haemodinamikai instabilitás stb.) szükséges [8, 9]. Ha a „menjünk biztosra” hozzáállást kívánjuk követni, hatásspektrumuk miatt csábító antibiotikumok lehetnek a carbapenemek. Ugyanakkor a carbapenemkezelés elrendelésekor ne feledkezzünk meg a carbapenemáztermeló kórokozókra és a nem fermentáló Gram-negatívokra gyakorolt szelekciós nyomásról. Ilyenkor inkább alternatív kezelések alkalmazására ösztönöznek a fent említett tanulmányban Gedik és mtsai. Vizsgálatuk során hematológiai kórképben szenvedő betegek bacteraemiás epizódjai során 75\%-ban sikerrel alkalmaztak carbapenemmentes antibiotikum-kezelést (pl. pipercillin/tazobaktám) [7].

\section{Célkitüzés}

A vizsgálat során célkitűzésünk a 2016. 01. 01. és 2018. 12. 31. között klinikánk Hematológiai Tanszékén kezelt betegek körében a véráramfertőzést okozó speciesek megoszlásának és antibiotikum-érzékenységének felmérése volt. Különös figyelmet szenteltünk azon kórokozóknak, melyek multirezisztens izolátumai meghatározzák az empirikus antibiotikum-kezelést. Adatgyűjtésünk nem terjedt ki a koaguláz-negatív Staphylococcusokra, amelyek a hemokultúrák leggyakoribb kontamináns baktériumai. Mivel ezek a törzsek a kanülasszociálta fertőzések leggyakoribb okozói, ugyanakkor antibiotikum-érzékenységük általában kedvezőtlen, esetükben pedig az irányelvek egyértelmüen vancomycinkezelést javasolnak, így a lokális érzékenységi adatok érdemben nem befolyásolják a helyi empirikus antibiotikum-választás stratégiáját.

Vizsgálatunk további célja annak felmérése volt, hogy az osztályon korábban elönyben részesített, carbapenem alapú kezelések helyébe lépő új antibiotikum-felhasználási elvek hatására mi módon alakulnak a helyi rezisztenciaviszonyok. Utóbbi során egyéb, pseudomonasellenes hatással bíró, neutropeniás láz esetén használható antibiotikumok (cefepim, piperacillin/tazobaktám) carbape- nemekkel egyenlő arányban történő felhasználására törekedtünk.

\section{Módszer}

A fenti időszakban a Pécsi Tudományegyetem Orvosi Mikrobiológiai és Immunitástani Intézetében működő Bakteriológiai és Kórházhigiénés Laboratórium által vizsgált pozitív hemokultúra-eredmények statisztikai feldolgozását végeztük. Egy betegtől származó, azonos pozitív eredményeket egyként kezeltük, így minden egyes pozitív eredmény külön betegre, illetve külön infekcióra vonatkoztatott bacteraemiaepizódnak felel meg. Az adatgyüjtés során az Országos Epidemiológiai Központ által kiadott, multirezisztens kórokozókról szóló módszertani levél ajánlásának megfelelő táblázatot alkalmaztunk a fenti célkitüzések szerint. A szakmai irányelveknek megfelelően levett vérminták vizsgálata minden esetben a BACTEC (Becton Dickinson, Franklin Lakes, NJ, USA) rendszer segítségével történt. A pozitív minták identifikálása 2016. 08. 01. előtt standard biokémiai módszerekkel, ezt követően MALDI-TOF MS segítségével, a rezisztenciavizsgálatok pedig az EUCAST irányelveinek megfelelő módon, korongdiffúziós, illetve gradiens-diffúziós vizsgálattal történt.

Az Országos Epidemiológiai Központ definíciója szerint multirezisztens E. coliról (MECO), illetve Klebsielláról (MKLE) akkor beszélünk, ha azok 3. generációs cefalosporinokra rezisztensek és/vagy szerzett ESBL- és/vagy AmpC-termelő a törzsnek bizonyultak. Multirezisztens $P$. aeruginosára (MPAE) jellemző, hogy az ellene hatékony antibiotikum-csoportok közül csak kettőre vagy kevesebbre érzékeny. Vancomycinrezisztens Enterococcus spp.-ről (VRE), szerzett vancomycinrezisztenciával rendelkező Enterococcusok esetén beszélünk.

\section{Eredmények}

A fenti időszakban, a korábban említett kritériumoknak megfelelően, 112 pozitív eredmény született. A kórokozók túlnyomó többsége, 75\%-a Gram-negatív kórokozónak bizonyult, ezen belül is az Enterobacteriaceae család adta a kórokozók 55\%-át (E. coli $31 \%$, E. cloacae $10 \%$, K. pneumoniae 14\%). Hematológiai betegek esetében a vártnak megfelelően magas volt a $P$. aeruginosa okozta bacteraemiák aránya is, az esetek $18 \%$-ában sikerült ezt a kórokozót izolálni. S. maltophilia 2 esetben (2\%) tenyészett ki a vérmintákból. Gram-pozitív kórokozók közül legjelentősebb a $S$. aureus aránya volt, $14 \%$, ezt az Enterococcusok követték 7\%-kal. S. pneumoniae-t az esetek $2 \%$-ában tudtunk izolálni. Külön szemlélve az egyes éveket hasonló eredményekhez jutottunk, az elmúlt évben még kifejezettebb Gram-negatív dominanciával (1. ábra). 


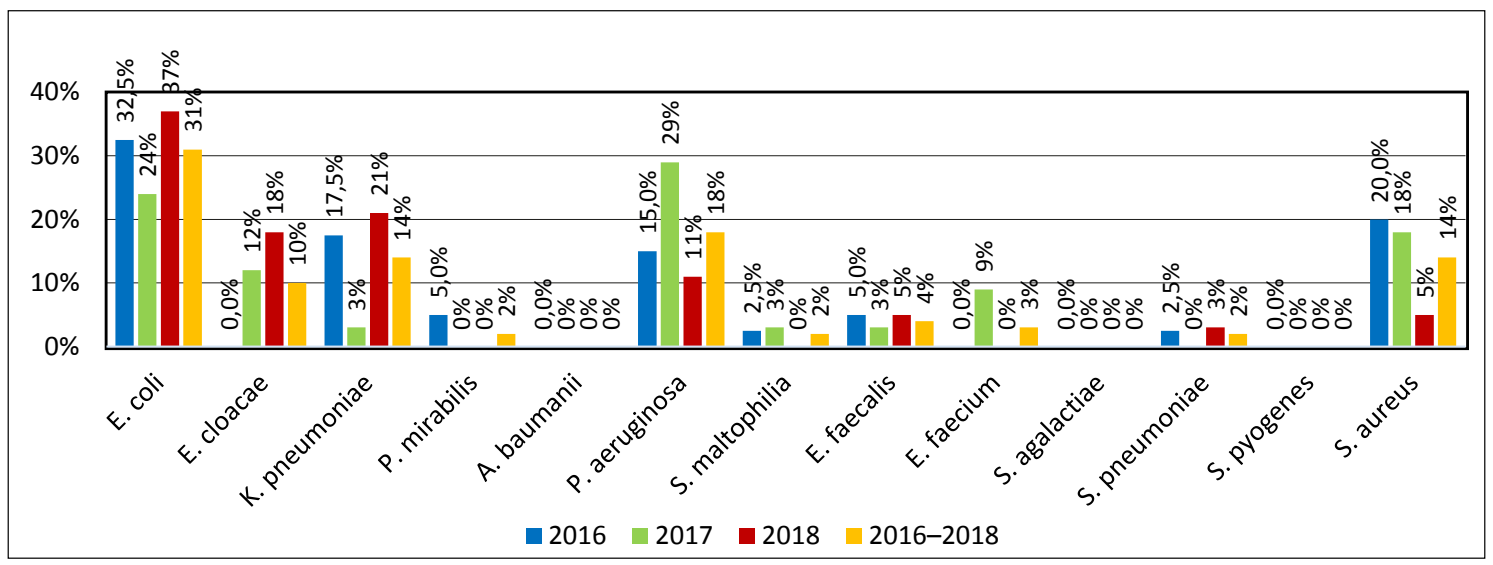

1. ábra. A kórokozók megoszlása évek szerint és a vizsgált időszakban összesítve

A fenti kórokozók közül talán legnagyobb terápiás nehézséget a $P$. aeruginosa okozza, hiszen még, ha nem multirezisztens törzsről van is szó, akkor is kevés kezelési lehetőség áll rendelkezésünkre. Ezért a $P$. aeruginosaizolátumok antibiotikum-érzékenységét érdemes részletesebben áttekinteni. A 2017-es országos eredményekhez viszonyítva magasabb arányú gentamicin- és amika- multirezisztens Pseudomonas spp., 2 (2,2\%) multirezisztens $E$. coli, 1 (0,9\%) vancomycinrezisztens Enterococcus spp. (VRE) (3. ábra). A vizsgált időszakban multirezisztens Acinetobacter-, S. maltophilia- és MRSA-fertőzés nem volt. Az Enterobacteriaceae családba tartozó öt multirezisztens törzs mindegyike érzékeny volt carbapenemekkel szemben. $P$. aeruginosa-izolátumok közül kettő

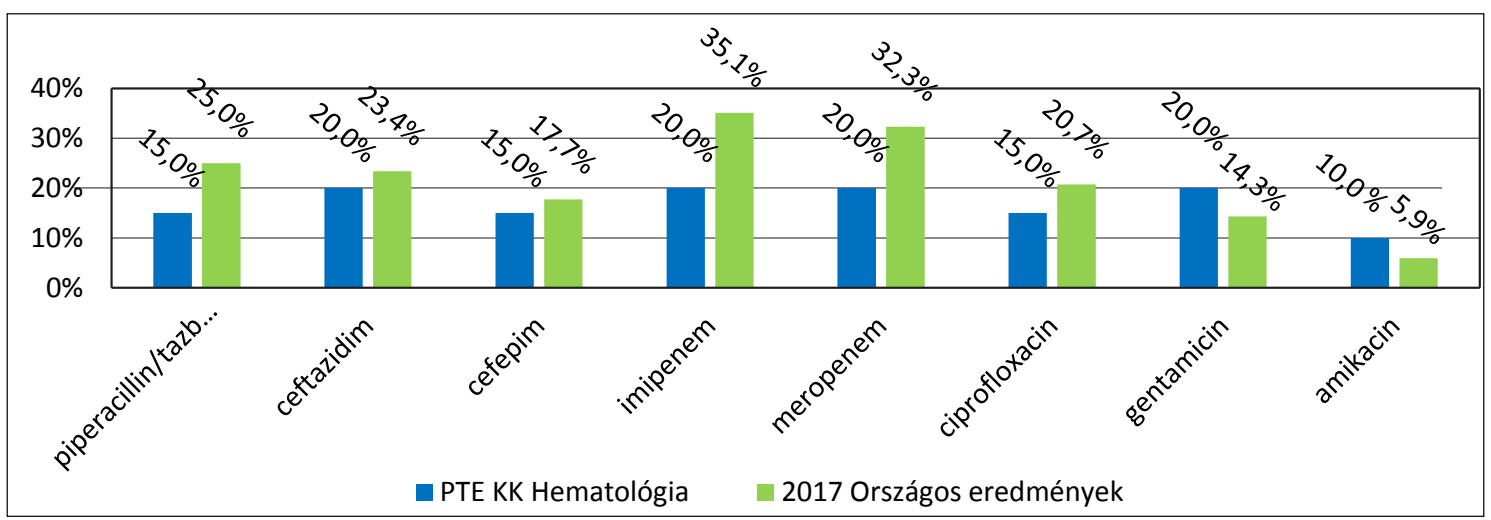

2. ábra. A $P$. aeruginosa antibiotikum-rezisztenciája. A kórokozó antibiotikum-rezisztenciája a vizsgált időszakban és a 2017. évi országos rezisztenciaeredmények. PTE KK = Pécsi Tudományegyetem, Klinikai Központ

cinrezisztencia mellett kedvezőbb béta-laktám- és ciprofloxacinrezisztencia igazolódott. Az összes izolátum 20\%-a (4-4 törzs) bizonyult rezisztensnek imipenemmel, meropenemmel szemben. Hasonló eredmények születtek ceftazidim és gentamicin esetén is. Piperacillin/ tazobaktámmal, cefepimmel, ciprofloxacinnal szemben kedvezőbb módon, az izolátumok 15\%-a (3-3 törzs) volt rezisztens, míg az amikacinrezisztencia 10\% (2 törzs) volt (2. ábra). Fontos azonban megjegyezni, hogy a vizsgált időszakban mindösszesen $20 P$. aeruginosa törzs került izolálásra, így azok antibiotikum-érzékenységi adataiból az alacsony esetszám miatt messzemenő következtetést nem lehet levonni.

Az izolált 112 törzsből a vizsgált időszakban 9 (az öszszes izolátum 8\%-a) bizonyult multirezisztens kórokozónak, 3 (2,7\%) multirezisztens Klebsiella spp., 3 (2,7\%)

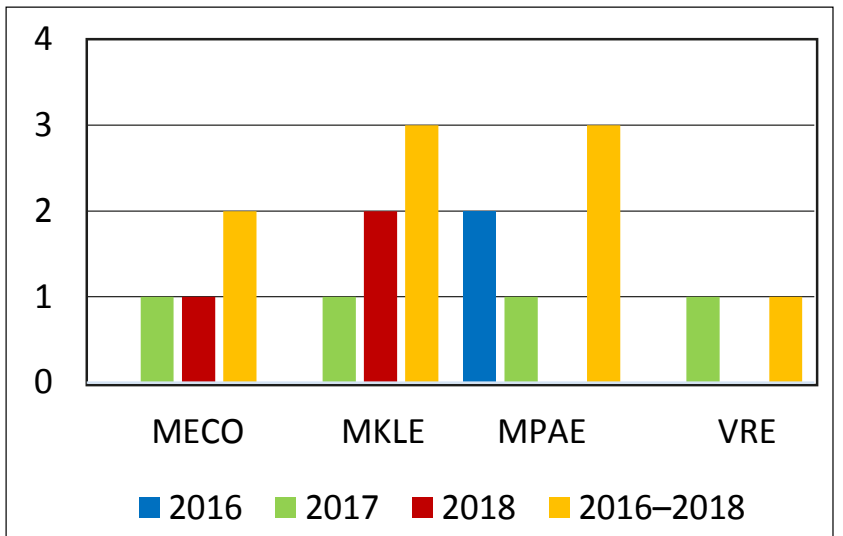

3. ábra. A multirezisztens kórokozók megoszlása évek szerint és a vizsgált időszakban összesítve. MEKO = Multirezisztens $E$. coli; MKLE $=$ Multirezisztens Klebsiella spp.; MPE = Multirezisztens P. aeruginosa, VRE = Vancomycinrezisztens Enterococcus spp. 
csak colistinre, egy pedig piperacillin/tazobaktámra és cefepimre volt érzékeny. Az egy VRE-izolátum érzékenynek bizonyult tigecyclinnel, linezoliddal és quinupristin/ dalfopristinnel szemben.

\section{Következtetések}

A vizsgált adatok alapján az látható, hogy a Pécsi Tudományegyetem Klinikai Központ I. sz. Belgyógyászati Klinikájának Hematológiai Tanszékén a véráramfertőzések legnagyobb részéért Gram-negatív kórokozók tehetők felelőssé. Az irodalmi adatoknak megfelelően, e csoporton belül is a $P$. aeruginosa és az Enterobacteriaceae család tagjainak dominanciája figyelhető meg. A P. aeruginosa törzsek körében magasabb carbapenemrezisztencia mellett piperacillin/tazobaktám, cefepim és ciprofloxacin tekintetében az eredmények kedvezőbbek. Megállapítható továbbá, hogy a Hematológiai Tanszékünkön a multirezisztens kórokozók előfordulása alacsony szintü, közöttük nagyobb arányban a multirezisztens Gram-negatív kórokozók (E. coli, Klebsiella spp., P. aeruginosa), kisebb gyakorisággal Gram-pozitív kórokozók fordulnak elő.

Mindezek alapján elmondhatjuk, hogy az irodalmi adatoknak, ajánlásoknak megfelelően az empirikus kezelésnél a $P$. aeruginosa kóroki szerepét minden esetben figyelembe kell venni. Emellett az Enterobacteriaceae család tagjai szintén meghatározóak az empirikus antibiotikumválasztásban. Az Enterobacteriaceae család tagjai körében észlelt alacsony multirezisztens arány, valamint a $P$. aeruginosa kedvezőtlen carbapenemérzékenysége ezen antibiotikumok empirikus kezelésként történő elsődleges felhasználása ellen szól. Emellett az is látható, hogy a tanszékünkön alkalmazott, a carbapenemek és más, pseudomonasellenes béta-laktámok kiegyensúlyozott alkalmazására törekvő antibiotikum-felhasználási elvek jelentősen nem emelik a multirezisztens Gram-negatívok előfordulását. Az eredmények alapján fontosnak tartjuk, hogy tartózkodjunk a carbapenemek széles körü, kizárólagos alkalmazásától, amivel ezzel nagy szelekciós nyomást gyakorolnánk a carbapenemrezisztens Pseudomonas aeruginosa- és carbapenemáztermelő Gram-negatív kórokozókra. Ugyanakkor a kis esetszám miatt hibás volna általános érvényü ajánlásokat megfogalmazni. Végezetül fontos emellett azt is megjegyezni, hogy a multirezisztens kórokozók terjedésének megelözésében a megfelelő antibiotikum-stewardship mellett elengedhetetlenek a higié- nés és izolációs szabályok és megfelelő surveillance alkalmazása.

Nyilatkozat: A közlemény más folyóiratban korábban nem jelent meg, és máshová beküldésre nem került. A levelező szerző elolvasta a szerzői útmutatót.

Anyagi támogatás: A közlemény anyagi támogatásban nem részesült.

Érdekeltségek: A szerzőknek nincsenek érdekeltségeik.

Szerzői munkamegosztás: S. D. eredmények feldolgozása, szöveges formátum megfogalmazása, Ny. A., K. K. nyers adatok gyüjtése, mikrobiológiai vizsgálatok elvégzése, P. Z. infektológiai konzulens, H. A. hematológiai konzulens. A cikk végleges változatát valamennyi szerző elolvasta és jóváhagyta.

\section{Irodalom}

[1] Munita JM, Arias CA. Mechanisms of Antibiotic Resistance. Microbiol Spectr. 2016; 4(2). DOI: 10.1128/microbiolspec.VMBF0016-2015

[2] World Health Organization. Antimicrobial resistance: global report on surveillance. 2014. Available from: http://www.who.int/ drugresistance/documents/surveillancereport/en/

[3] National Center for Epidemiology. Prevention of bacterial infections caused by multidrug-resistant bacteria guideline. [Módszertani levél a multirezisztens kórokozók által okozott fertőzések megelőzéséről] 2016 Available from: http://oek.hu/oek.web?to= $16 \&$ nid=444\&pid=1\&lang=hun [Hungarian]

[4] Weintrob AC, Sexton DJ. Susceptibility to infections in persons with diabetes mellitus. 2017 Available from: https://www.uptodate.com/contents/susceptibility-to-infections-in-persons-withdiabetes-mellitus

[5] Weinstein MP. Positive blood culture. Clin Adv Hematol Oncol. 2010; 8: 850-851.

[6] Gedik H, Simsek F, Kantür A, et al. Bloodstream infections in patients with hematological malignancies: which is more fatal cancer or resistant pathogens? Ther Clin Risk Manag. 2014; 10: 743-752.

[7] Tóth E, Hajdú E, Piukovics K, et al. Bacteria causing bloodstream infection in acut leukaemia patients [Véráramfertőzést okozó baktériumok akut leukémiás betegeknél] Bulletin of Medical Sciences [Orvostudományi Értesítő] 2007; 80: 32-34. [Hungarian]

[8] Infectious Diseases Society of America. Clinical Practice Guideline for the Use of Antimicrobial Agents in Neutropenic Patients with Cancer. 2010 Available from: https://academic.oup.com/ cid/article-abstract/52/4/e56/382256

[9] Sinkó J. Treatment and prevention of infections in oncology patients with neutropenia [A neutropeniás onkológiai beteg infekcióink kezelése és megelőzése]. Hungarian Oncology [Magyar Onkológia] 2011; 55: 155-163. [Hungarian]

A cikk a Creative Commons Attribution 4.0 International License (https://creativecommons.org/licenses/by/4.0/) feltételei szerint publikált Open Access közlemény, melynek szellemében a cikk bármilyen médiumban szabadon felhasználható, megosztható és újraközölhető, feltéve, hogy az eredeti szerző és a közlés helye, illetve a CC License linkje és az esetlegesen végrehajtott módosítások feltüntetésre kerülnek. (SID_1) 